\title{
National archives and records - the legal and policy considerations for the UK
}

\section{Stephen Saxby}

\author{
School of Law \\ Southampton University, UK \\ E-mail: S.J.Saxby@soton.ac.uk
}

\begin{abstract}
Public Sector Information (PSI) is a strategic resource without which government could not function. It feeds directly into policy formation and growing volumes of personal and cultural information are in constant demand, fulfilling a wide variety of personal and business needs. Whereas traditional conduits for the supply and publication of such material were confined to the printed page and broadcast media, digitisation has opened up substantial new means for delivering access to these resources. This 'access revolution' has itself created a new array of issues about what types of material should be captured to form the national archive and what intellectual property rights apply. One important aspect is the less discussed issue of policy for the maintenance and development of the public archive. Mass digitisation of the public record requires investment and secure maintenance if the archive is to be sustained. So what kind of regulatory structure needs to be established to facilitate this? Moreover, how far should private sector participation and expertise be utilised? On what basis should proprietary and user rights be granted where such collaborations take place? Finally, what message comes out of this as regards regulatory reform for libraries and archives?
\end{abstract}

Keywords: national archive; intellectual property rights; library privilege; born digital; Digital Britain; s.42 CDPA 1988.

Reference to this paper should be made as follows: Saxby, S. (2010) 'National archives and records - the legal and policy considerations for the UK', Int. J. Private Law, Vol. 3, Nos. 1/2, pp.43-69.

Biographical notes: Stephen Saxby (BA, Cert.Ed., MBCS, PhD, Solicitor) is Professor of IT Law and Public Policy at the University of Southampton and Deputy Head of School (Research). He is the Editor of The Computer Law and Security Review - The International Journal of Technology Law and Practice (Elsevier; www.compseconline.com) and The Encyclopedia of Information Technology Law (Sweet and Maxwell). He specialises in e-government, public information and geospatial policy in the UK.

\section{Introduction}

One might have thought that the onset of digitisation would have brought forward a fairly straightforward policy for archiving Public Sector Information (PSI) and other chosen material. For newly created PSI it would be a simple matter of depositing it in some form of database within a licensing policy dictated by Crown copyright. For existing material, 
in hard copy form, selected information would need to be digitised and then made available under a similar policy regime. Just a modicum of research below the surface of this issue reveals a much more complicated picture raising issues about what should be selected, how this should be archived, what technical standards should apply, who should undertake the work and what kind of legal framework is needed. In addition to that are broader issues of access rights, collaboration with the private sector, ownership and oversight of the process and creation of an enduring policy that will serve not only the people today but, importantly, future generations as well.

\title{
2 The organisational framework for archived PSI in the UK
}

A sound and coherent policy towards the maintenance development and management of archives and records is central to any effective national policy. Without this ingredient in place there can be no effective arrangements put in place for accessing and sharing PSI either within government or the public at large:

\begin{abstract}
"Information if the lifeblood of government. Without it, decisions cannot be made, evidence-based policy cannot be formulated and public services cannot be effectively delivered to society. To deliver world class public services and guarantee public accountability, government must ensure it is capturing and effectively managing the information it is creating and receiving. Relevant information must be kept for long-term accountability and personal data must be held securely, in order to maintain the citizen's trust in government."1
\end{abstract}

It is an absolute given of course that while a successful PSI policy is vital to its effective exploitation and use for today's purposes, the decisions taken now as to the wider development of a preservation strategy are vital to the custodianship of the UK's cultural heritage. This is so that future generations may enjoy access to a substantial archive of such material in secure and usable formats. To begin to understand how UK policy is currently working it is necessary to identify the organisational structures that have been put in place, the legal framework governing their activities and finally the strategy adopted to deal with the transition of information storage from what used to be an exclusively hard copy media into predominantly digital storage.

Since May 2005, when the Office of Public Sector Information (OPSI) was formed, OPSI has become the principal focal point for PSI re-use in the UK with management responsibility that "embrace official, legal and statutory roles across publishing, UK legislation, licensing, Crown copyright and database policy and regulation of the re-use of PSI". 2 In October 2006 OPSI merged with The National Archives (TNA) - a UK government department and executive agency of the Ministry of Justice with responsibility for preserving and protecting the official archives - "one of the most important collections in the world, holding public records dating back almost 1000 years". Its main facility is now at Kew in Southwest London.

In addition to the above is the British Library (BL) - the national library of the UK which, for the past 250 years, has collected more than " 150 million items, in over 400 languages, to which three million new items are added every year". This makes it one of the largest libraries in the world. In 1998 it moved to new headquarters in St. Pancras - the largest public building to be constructed in the UK for 50 years. ${ }^{4}$ Management of the library was established by the British Library Act 1972 (BLA) which also consolidated the merger of eight other institutions including The British Museum Library 
and the National Lending Library for Science and Technology. BLA gave BL the remit to be a "national centre for reference, study and bibliographical and other information services, in relation both to scientific and technological matters and to the humanities". 5 Management of BL is placed by BLA in the hands of the British Library Board with responsibility to secure this remit. BL is also the lead deposit library in the UK which, since the Copyright Act 1911, has ensured the delivery to BL of every book published in the UK within one month of publication. ${ }^{6}$

\section{The legal position - library privilege under the Copyright Act}

The current law governing the rights of prescribed libraries or archives to make copies of literary, dramatic and musical works held in permanent collections in order to ensure their preservation and replacement, is set out in s.42 Copyright Designs and Patents Act 1988 (CDPA). This provides that:

Copying by librarians or archivists: replacement copies of works

(1) The librarian or archivist of a prescribed library or archive may, if the prescribed conditions are complied with, make a copy from any item in the permanent collection of the library or archive-

(a) in order to preserve or replace that item by placing the copy in its permanent collection in addition to or in place of it, or

(b) in order to replace in the permanent collection of another prescribed library or archive an item which has been lost, destroyed or damaged,

without infringing the copyright in any literary, dramatic or musical work, in any illustrations accompanying such a work or, in the case of a published edition, in the typographical arrangement.

(2) The prescribed conditions shall include provision for restricting the making of copies to cases where it is not reasonably practicable to purchase a copy of the item in question to fulfil that purpose.

The principal purpose of this measure is to "minimise wear and tear of fragile items or to replace lost, destroyed or damaged items" housed in those collections.7 The Gowers Review of Intellectual Property ${ }^{8}$, commissioned by HM Treasury in December 2005 to offer an independent view of the fitness for purpose of intellectual property law in an increasingly global and digital environment, proposed relaxations to the scope and content of s.42. The review argued that CDPA should be amended "to permit libraries to copy the master copy of all classes of work (including sound recordings, films and broadcasts) in a permanent collection for archival purposes and to allow further copies to be made from the archived copy to mitigate against subsequent wear and tear". 9 In addition libraries should be permitted to 'format shift' archival copies to ensure that records do not become obsolete. ${ }^{10}$

In its consultation on the issue, UK Intellectual Property Office (UK-IPO) invited comment on the key issues including what impact the expansion of the exception would have for libraries and archives, the consequences of extending the section to cover all classes of works, whether there was a need to restrict the number of copies made for preservation purposes and the impact for right-holders if the proposals were to be extended to cover museums and galleries. ${ }^{11}$ 
In its response Barbara Stratton, Senior Policy Adviser of the Chartered Institute of Library and Information Professionals (CILIP) welcomed the copying for preservation proposals but noted that no exception was proposed for circumvention of Technological Protection Measures (TPMs) for preservation, which was now permitted for example in Norway ${ }^{12}$ and in new law in Finland. The author noted with interest a proposal by the UK libraries and Archives Copyright Alliance (LACA) that legislation be brought forward to permit 'trusted' institutions, such as the legal deposit libraries and others, to be given either the keys to facilitate circumvention of TPMs or TPM-fee copies for specific purposes such as preservation, etc. ${ }^{13}$ In its response ${ }^{14}$ the British Library agreed with Barbara Stratton on this issue and with the Review's proposals for extending the exceptions within s.42 commenting that, without these measures, "digital material will not be available for future generations":

\begin{abstract}
"A situation where, in the main, public employees are effectively required to break the law by infringing a DRM, or making a copy of an archival copy of a secondary work while it is in copyright, in order to perform their statutory requirements as a library, would seem one that any responsible copyright law must seek to avoid. The lack of clarity around the preservation exception, where seemingly literary, dramatic and musical works can be archived for preservation purposes but artistic, sound, film and broadcast not, is one example of where UK copyright law applies exceptions in a non-standard and illogical manner. In order to create a fit-for-purpose copyright law respected by right holders and users alike we believe that the preservation exception is one of a number of areas where common sense rationalisation of the law is required." $" 15$
\end{abstract}

It was also important to recognise that format shifting was a fundamental aspect of digital archiving where preservation of the original digital file is in part "dependent upon the software and hardware with which the files interact". As such, format shifting was essential "to guarantee their accessibility by future software formats".

\title{
3.1 The contract impediment
}

Of equal interest and importance to the problems of archiving was another section of the BL submission dealing with what it called "substantive copyright issues not covered in the consultation". One of these was the assertion that a substantial amount of information in electronic form was framed in effect, not by copyright law, but contract law, which took precedence over copyright law when the contract was freely entered into by two parties.

Commenting on this issue, Charles Oppenheim, Professor of Information Science at Loughborough University has said: "Copyright offers a balance between private economic interests and the public
interest in enhancing scholarship, creativity and recreational use of materials
created by others. The public interest is protected by means of a series of
exceptions to copyright, such as that of fair dealing for non-commercial
research or private study. It is therefore a matter of great concern that these
exceptions to copyright, enshrined in the law, are being undermined by
contracts and/or technical protection measures that prevent bona fide users
from enjoying those exceptions. Given the importance copyright exceptions
have for a creative, social and scholarly society and well being, I think there are 


\begin{abstract}
few other areas of public policy that need to be addressed more urgently than that of restricting the ability of contracts or technical protection measures to over-ride exceptions to copyright."
\end{abstract}

$\mathrm{BL}$ argued that the common use of licensing agreements that accompanied electronic versions of works effectively "trumped" copyright law and the traditional "trade-off" between the award of "monopolistic rights" to the copyright owner "in return for the limited exceptions [offered] during the copyright period of a work". The net result was that those exceptions were being systematically undermined by contract, despite the fact that they were provided for by statute. BL noted that the majority of electronic content acquired by libraries today was "pre-packaged for a global market" which inevitably required adherence to terms and conditions that bore little account to UK law or the traditional functions of libraries. It cited for example business databases created and licensed "with internal business use in mind and not use by readers in the context of a publicly accessible reading room". 16

A random survey of 100 contracts offered to BL from throughout the world confirmed either deliberate or accidental undermining of the exceptions and limitations provided for in UK law such as fair dealing, inter-library loan and access for the visually impaired. Only 23 licences dealt explicitly with archiving and presentation of material while 19 forbade archiving for a variety of reasons. The remaining 58 were silent on the issue. In a number of cases where archives were permitted, the licensor claimed post-termination rights to the archive developed by the subscribing institution. Otherwise, a typical clause preventing archiving might state:

\footnotetext{
"on termination of this Agreement, the Licensee agrees to destroy all Licensed Material stored on any digital information storage media, including, but not limited to, system servers, hard disks, diskettes and back up tapes."
}

In BL's view this general situation clearly raised public policy issues about public funding being used for "acquisition" of content. ${ }^{17}$ In circumstances where the licence forbade archiving and preservation this left potentially large holes in the policy for long-term collection development in the UK, and undermined the self-sufficiency of libraries in information provision.

To tackle these problems BL recommended a change to the law to provide that licences and contracts be prevented from overriding the limitations and exceptions in copyright law. It cited Portugal, Ireland and Belgium as examples of Member States in which such exceptions within domestic copyright law may not be undermined. Moreover, it indicated that it was not aware that any material problems arose for rights holders as a result of the pre-eminence of copyright over contract in these jurisdictions. A similar approach within the UK would ensure that a clearer exceptions regime, working in the public interest, could not be undermined by private interests, especially in the digital world; that a fit for purpose exceptions regime would provide a balance for both rights holders and users; that any potential conflict between domestic copyright law and databases on this point would be ironed out; and that the costs currently falling on the public sector to "negotiate and implement differing terms and conditions" would be minimised. ${ }^{18}$

Discussions with librarians and digitisation specialists within Southampton University library, which has built up a considerable pool of knowledge about the process over many years now, suggests that the contractual impediment extends even further into the 
archival process. For them a problem of equivalent significance concerns third party liability that may arise from any archiving of existing material under copyright. A risk adverse policy has been adopted by Southampton so that some projects have had to be turned away for fear of potential liability to third parties who may have contributed in the past to the material proposed for archiving. An example might be of a post war hard copy national magazine series to which, over the years, hundreds of contributors may have submitted material. The first problem for the proposed archivist is to ensure that the publisher can deliver the necessary permissions to enable digitisation to take place free of any risk of copyright infringement claims from the contributors. A second, more significant problem, concerns the moral rights of authors should the archive be placed online for public access. If works are then lifted from the archive and placed on other internet sites, perhaps in inappropriate forms or contexts, then an issue of liability to those authors may additionally arise against the archiving library that placed the material online in the first place.

Whether or not there is anything than can be done to authenticate the document or to limit its use, either in terms of statements embedded in the signature code of the document or in metadata, remains to be seen. The net result of these concerns, however, is that perfectly sound archiving proposals, that may carry great social or historical significance for future generations, are being turned down because of concerns as to the potential liabilities that may arise. Whether, in the long term, methodologies can be developed to secure the integrity of documents in particular web locations and to prevent inappropriate use, either in whole or in part, might be investigated. Aspects of this issue are certainly being raised by the UK Government in its copyright strategy:

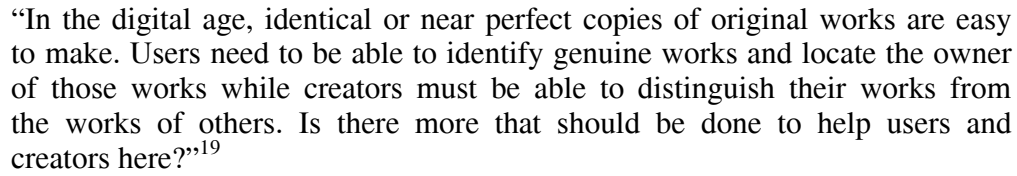

For the time being, however, only a robust 'notice and take down procedure' is likely to be effective and that will most certainly not be welcomed by internet service providers.

Reading between the lines it would appear that further consideration of the proposed reforms to library privilege, subject to the original UK-IPO consultation, is not seen as urgent. This will enable the Government to focus on what it sees as the more immediate priorities of tackling online piracy, unauthorised re-use of content over the internet and the broader challenges of the digital economy. It is more than one year now since the April 2008 deadline for submissions passed and the Government has not, so far, shed clear light on what is likely to happen next in relation to the s.42 CDPA reform agenda. The opportunity, as Lord Triesman - Parliamentary Under Secretary of State for Intellectual Property and Content - put it in his foreword to the copyright consultation, ${ }^{20}$ "to help the Government consider the optimal location of the boundaries, through the appropriate operation of any exceptions", may have narrowed its focus to the needs of the creative industries and the UK economy. The current position was set out by UK-IPO Chief Executive, Ian Fletcher, in March 2009 when he indicated that summer 2009 "will be too early for the final report on our work". In the meantime libraries continue to operate with existing exceptions within a copyright policy in need of reform. 


\section{EU policy on archives and digital libraries}

\subsection{Strategy for creative content online and the knowledge economy}

At the centre of EU policy for the information society is its i2010 strategy, first presented in June 2005 as a five year plan. ${ }^{21}$ Its three aims are:

1 to "create a Single European Space" designed to promote an "open and competitive internal market for information society and media services"

2 to "strengthen investment and innovation in ICT research"

3 to "support inclusion, better public services and quality of life through the use of ICT". 22

The aim of the first objective is to secure a "sound market basis for the European content sector" and to enable it to distribute "its great variety of content on a European and global scale". 23

With regard to EU copyright policy a strategy for creative content online has been developed, designed to find 'pragmatic solutions' to enhance the availability of creative content online and to look in the medium term to the need for regulatory reform. ${ }^{24}$ Of main interest here to archiving policy development is the analysis of ways to improve the management of copyright online and particularly the use of DRM and TPM. A wide consensus exists for consumers to be made aware of what they can and cannot do with the content - copy restrictions, etc., while DRM should be as "interoperable as possible, allowing portability of content from one device to another". ${ }^{25}$ In addition, with regard to determining whether use of the content of a work is illicit or not, the strategy endorses development of content recognition techniques such as 'watermarking' or 'fingerprinting' that would allow identification and retrieval of content used illicitly. Such developments, if successful, could go some way to alleviating the concerns of archivists as to their liability for the illicit use of archived material placed online. ${ }^{26}$

The British Government, however, while welcoming the Commission's recognition that creative content is important to the future of the audio-visual industry in Europe, urges caution before legislative action is taken in a fast moving and complicated environment. On DRM reform, for example, it calls for further evidence of the problems facing the creative industries and argues that the variety of approaches towards DRM across Europe militates against a "one size fits all" arrangement at the present time.

A second and perhaps more directly relevant initiative to the regulatory reform of archiving policy is the Green Paper on Copyright in the Knowledge Economy, adopted in July 2008. ${ }^{27}$ The aim of the Green Paper is to examine the role of copyright in the 'knowledge economy' ${ }^{28}$ and particularly to examine "how knowledge for research, science and education can best be disseminated in the online environment". ${ }^{29}$ One of the specific issues canvassed relating to copyright exceptions and limitations concerns exceptions for libraries and archives. Two core issues are identified. The first relates to the production of digital copies of materials held in libraries' collections and the second to the delivery of these copies to users. Digitisation could secure such delivery online and it could also preserve content for future generations, but potential defects were present in the legal framework of the copyright since no "blanket exception" existed for libraries and archives to reproduce works necessary for their preservation. National rules were 
also unclear as to the extent to which "format shifting" was possible or the numbers of copies that could be made for archival purposes. Policies of Member States were at different levels of complexity and scope.

The Green Paper notes the growing enthusiasm among libraries and other public interest establishments to both preserve works by digitisation and disseminate them online. This would mitigate the need in some cases for consumers to personally visit archive premises. Digitised catalogues could list the availability of online databases where such archived material might be stored and accessed for a fee.

Present EU law for publicly accessible libraries, educational establishments, museums or archives is set out in Art. 5(2)(c) of the Copyright Directive: ${ }^{30}$

\section{Exceptions and limitations}

Member States may provide for exceptions or limitations to the reproduction right provided for in Article 2 in the following cases:
(a).... [text not inserted]
(b) $\ldots$ [ ditto ]
(c) in respect of specific acts of reproduction made by publicly accessible libraries, educational establishments or museums, or by archives, which are not for direct or indirect economic or commercial advantage.

There is also a narrow exception in Art. 5(3(n) for research or private study in which the material was accessed from "dedicated terminals on the premises or establishments referred to in para 2(c)".

An additional issue concerns private investment in large scale digitisation of works, such as the Google's 'Book Search Project', which commenced in 2005 via agreements entered into by Google with European libraries regarding digitisation of works in the public domain. Other private sector activity is also springing up, such as the provision by publishers within their portfolios, of online access to parts or full texts of books for commercial purposes. Such activities fall outside the Art. 5(2)(c) exception, and involve the exercise of the reproduction right for which right-holder permission is required for scanning to occur.

The Green Paper fails at this point to develop any discussion about the distinction between reproduction of material for archival purposes and the development of online resources for immediate commercial exploitation within the private sector. Clearly, there is a much broader debate to be had here as to the use of copyright exceptions to permit archiving where the organisation responsible is under a public duty to do so within a defined policy for future custodianship of the material. To what extent private sector participants should be encouraged to engage in archiving activity on behalf of libraries, etc., will crucially depend upon enquiry as to the contract terms by which the archived resource will be sustained and made available thereafter. It is in the public interest to ensure that such archives do not become the 'property' of the private sector operator from the point of creation, such that control is lost of the ability to satisfy the obligation to sustain and preserve the archive for future generations under acceptable access arrangements both now and in the future.

Demand for public access to works such as photographs and audiovisual works with an educational, historical or cultural value held by libraries, museums and archives can be strong. Digital restoration of such works can also be part of an archive policy. The Green Paper addresses this issue in relation to 'orphan works', i.e., works still in 
copyright but whose owners cannot be identified or located. The European Commission has recommended ${ }^{31}$ that Member States consider mechanisms to use orphan works and promote the availability of lists of such works. It endorses the recommendations of a High Level Expert Group on Digital Libraries ${ }^{32}$ containing guidelines on "diligent search for right holders and general principles concerning databases of orphan works and rights clearance mechanisms". The Green Paper calls for harmonisation across borders on this matter.

\subsection{Responses to the Green Paper}

In its response to the Green Paper, ${ }^{33} \mathrm{BL}$ pointed out that it well understood the importance of copyright to the knowledge economy "as a tool to manage and control the flow of scholarly information to create a well-educated and democratic society". It had a direct and probably unique experience as a legal deposit library which included being a purchaser of content (with an acquisition budget of $£ 16.7$ million in 2007-2008), licensee from publishers and collecting societies; publisher of databases, CDs and books; clearer of rights and exerciser of copyright exceptions permitted by law. Drawing upon that cumulative experience BL criticised the Commission and its Green Paper for systematically underestimating "the importance, interest and stake that European citizens have in the uninhibited flow of knowledge in the EU". For example, it pointed to the fact that one day after launch of 'EUROPEANA' ${ }^{34}$ in November 2008 - the EU and private sector sponsored multi-lingual European digital library, the site crashed having received up to 13 million hits per hour - some three times the expected level anticipated by the European Commission. ${ }^{35}$

BL echoed the response of SURF - the collaborative organisation for higher education institutions and research institutes aimed at "breakthrough innovations in ICT", that the Green Paper was "too one sided and seems to naively equate the interest of a commercial entity, with the wider interest of research and scholarship". BL noted that, in 2007 , across the EU libraries had spent $€ 4.25$ billion on content acquisition. It concluded that "legal certainty as to how this material may be used can only be created properly through copyright law". It was the duty of national and supra-national legislators to balance the "competing and conflicting interests of the user with those of the rights holders" but this was not being achieved within EU systems of public law, as copyright law continued to be undermined by the law of contract. The net result was that libraries were beginning to shun the purchase of scientific and research databases, on contract grounds, which were too restrictive and negated the role of exceptions. Offering mere 'guidance' or 'encouragement' as to the use of copyright exemptions between right holders and users, as posited by the Green Paper, was unlikely to "protect the public interest in any way".

These same issues, of course, also permeate throughout the debate about the effectiveness of archive policy and the practical and legal arrangements for its delivery. At issue, particularly, are the potential conflicts of interest, motivations and goals that arise among right holders, archivists, private sector participants and potential users of works identified as relevant or viable for preservation or restoration. In BL's view this was a critical issue: 


\begin{abstract}
"The sustainability and fragility of digital information, however, needs to be understood by the Commission. Digital preservation requires the normalisation of digital content, away from the part-open/part-proprietary nature of the majority of publisher produced databases. It then requires onward format shifting. This is an activity very different in nature to the market driven dynamic of publishers, the majority of whom will probably not have the expertise or the impetus to preserve large swathes of digital content of varying economic value. The preservation of a country's cultural heritage cannot be compared or likened to the very different role of a publisher. It requires institutions whose permanence is not questioned and which can work with a planning horizon that covers decades. No private enterprise is ever likely to meet these criteria." 36
\end{abstract}

Such views are endorsed by the Libraries and Archives Copyright Alliance (LACA) ${ }^{37}$ which, in their response ${ }^{38}$ to the Green Paper, argued that it failed to appreciate that libraries and archives cared for and made available a "very wide range of material well beyond the output of commercial publishing and sound recording and film production". Since the life span of such material tended to be short-lived much of it would otherwise be lost to the public. LACA argued that such "knowledge goods" by no means whatsoever represented every category since they also comprised works created on a non-commercial basis to "promote knowledge rather than to make money". Such works should be exchanged between people and not-for-profit institutions for "education, research and creativity".

LACA also recognised the work of libraries and archives in "preserving and making all kinds of knowledge goods available". This contributed greatly to Europe's economy, culture, education and research. It concluded that the duty of publishers and producers was to produce profits for their shareholders which the preservation and management of archival material was unlikely to achieve. No private or commercial enterprise would therefore be interested in participating in such work unless the copyright exceptions could be suitably amended by contract. The net result according to LACA was that "only permanent institutions such as libraries, archives and museums, which can plan ahead by the century, are in a position to take the long view required to preserve human memory".

The response $\mathrm{s}^{39}$ of the British Government to the Green Paper was more equivocal. On the issue of guidelines or encouragement as to contractual arrangements between right holders and users it was clear that the key principles needed to be articulated in the legal framework itself. If so then guidelines might be useful in demonstrating "how the relevant legal principles are or have been interpreted in practice". They might also be useful where technological developments are "moving ahead of the capacity of the legislation to address them".

With regard to libraries and archives, etc., entering into licensing schemes with the publishers, the Government stated that it was not aware of access problems for libraries wishing to subscribe to use such material. It was important to ensure that publishers did not lose sales should libraries set out to grant access to material on terms more favourable than might have been negotiated on the open market. Referring to the scope of the exception for publicly accessible libraries, etc., the Government was concerned to let the Gowers Review run its course, particularly with regard to broadening the UK's current exception in relation to the preservation of works.

In summing all this up it would seem that there is some overlap between the concerns of libraries to deliver the widest possible range of material to the user and the responsibilities that such institutions have to archive material in a form that can be 
handed on to future generations. Much reference was made to the fact that a considerable volume of material is unpublished in which the right-holder is rarely identified or found. It would seem that whilst clearance mechanisms might be established internationally, based upon a search process to try and identify right holders, further issues will arise as to whether such material may only be accessed on site as opposed to online via the internet. There are also national differences and inequalities of 'usage rights' to information once such material becomes accessible.

It is true that, whilst many publishers and producers may have no commercial interest in the digitisation of public domain and orphan works, and to some extent with much unpublished potential archival material, it remains impossible to imagine that libraries and archives can safely rely on publishers and producers to deliver the remainder. As LACA pointed out, the latter "do not continue forever: they go out of business and disappear, rendering orphaned any works in which they still have rights; they are taken over and absorbed into bigger conglomerations and are forgotten and in time become less easy to trace. Often current publishers and producers have little idea of what rights they had acquired through past mergers". 40

The solution, it argues, is for libraries and archives to have the "surety of being able to put their materials on publicly accessible online networks, including the internet, within the parameters of the Three Step Test". ${ }^{41}$ The latter refers to Art 9(2) of the Berne Convention $^{42}$ and Art 13 Agreement on Trade-Related Aspects of Intellectual Property Rights (TRIPS) ${ }^{43}$ to which the European Community and its Member States are bound. This permits countries to enact statutory exceptions for reproduction of works if this occurs within the bounds of three criteria:

1 certain special cases

2 no conflict with normal exploitation of the work

3 cannot unreasonably prejudice the author's interests.

LACA concludes that "it would benefit the public interest considerably if Information Society Directive Art. 5(2) were amended to explicitly reflect this". ${ }^{4}$

It remains to be seen, however, whether the UK Government would endorse such a robust change in the law, at least without further evidence and consultation. There may be much material that could be released without eroding legitimate economic returns to publishers, but it is a step beyond the current UK model for the capture of the UK's published output by the six prescribed legal deposit libraries, where publications are recorded in the online catalogue and the publications themselves are made available in the various Reading Rooms of BL. However, in its response to the Green Paper, the Government has opened the door to such discussion with the following statement:

"Remote access to digital files that are legally deposited material will create the probability of material being subsequently copied and shared locally. This does not comply with the Legal Deposit Libraries Bill. Although it seems reasonable to allow remote access to and digital copying of online collections held at legal deposit libraries for educational and research purposes, usage must comply with the Berne Convention and the 3-step test. We are currently considering the copyright exceptions in relation to education and research as we take work forward on the Gowers recommendations. No final decisions have yet been made in this area. In other cases, such as unpublished, or out-of-print (but still in copyright) works, which are no longer commercially available, and for which no commercial exploitation seems likely, there may be a case for 
exploring whether and how libraries and archives could best develop online access to their collections, taking into account the requirements of the Berne 3-step test." 45

Up to this point there has been little discussion of the relationship between proposals for legislative reform to support archival services and archive policy itself for the development of a sustainable future for materials either currently in its care or coming to it in the future. This issue devolves around both the policy for custodianship of the official archive of the British Government, maintained by TNA, and the mass of additional material held in private collections or more ephemerally in digital form or on websites. What guidance and strategies exist to guide archivists and others as to the selection and safe keeping of such material and what are the priorities for the future?

\section{UK archive policy towards digital preservation of works}

\subsection{The initial response to the digital revolution}

Given the history of UK and of the group of nations it comprises, there is no doubt that the importance of archives is domestically well understood as "the uninterpreted and authentic voice of the past". ${ }^{46}$ Reference is frequently made to the importance of iconic records of great historical interest. One such is the Domesday Book where, despite digitisation, it must be said that the more secure and accessible record still lies in the original manuscript. Reference must be made to the BBC Domesday Project of 1986 that subsequently became an outdated standard. ${ }^{47}$ The original benchmark statement of Government archive policy in the digital era dates back to December 1999 when the then Lord Chancellor's Department published a policy paper on the issue. ${ }^{48}$ The key aims of any archive were to "select the most important records for long-term safe keeping; to ensure they are then safely preserved and stored and properly managed and to ensure that everyone who needs to can have ready access to them". The Government went on to commit itself to develop its thinking on a number of specific issues including selection, access to records and archives, records management, digital records, preservation, resources and management and development of standards and performance levels. ${ }^{49}$

Other reports followed over the next four years dealing with different aspects of the policy. In 2001 a third edition of the manual on access to public records was published by TNA and endorsed by the Lord Chancellor's Advisory Council on Public Records. This essentially explained the operation of the Public Records Act 1958 (PRA) which standardises arrangements for the transfer of records to TNA. ${ }^{50}$ Also in 2001 the National Preservation Office (NPO) examined the principles relevant to a national preservation strategy for UK and Irish library and archive collections. In 2002 a commissioned report $^{51}$ for the Council for Museums, Archives and Libraries UK looked into the current picture, combined with analysis of specific needs of the archive domain, based on surveys, interviews and desk-based research. The report was particularly disturbed about a number of issues concerning electronic records concluding that, if ignored, this would mean that archives faced the loss of "vast amounts of historical and evidential records".

The broader debate about the future of libraries featured in February 2003 when DCMS published its "long term strategic vision for the public library service". ${ }^{2}$ It recognised that more people visited public libraries than cinemas and football grounds and called for a public library service that was less fragmented and better able to deliver services "tailored to the needs of distinctive localities". 
In August 2003, TNA published a Consultation Paper to canvas opinion on legislative changes to records management and archives based on the proposition that present controls were "old and inconsistent". These took "no account of digital records including emails" or "the huge increases in the volume and complexity of information and records and the wide market the digital revolution has created for electronic access to information, particularly via the Internet". The outcome of the consultation, published in March 2004, showed strong support for its original proposals, subject to the resource implications of any changes. It envisaged that the findings would be considered when revised proposals were developed. Then, in July 2004, the Comptroller and Auditor General reported on the effectiveness of British Library services that could be accessed remotely, particularly document supply services and the strategic challenges it faced as the digital environment developed.

An informative, independent assessment, of progress in these areas came in 2004 in the report of the Archives Task Force to the Museums, Libraries and Archives Council (MLA). It began by assessing the "rich variety of archival sources" noting that archives existed in many different locations and forms. Public archives were "well established through the work of the national archives, local authority-run record offices, local studies libraries, universities and further education institutions, and the records management services of public organisations". ${ }^{53}$ While legislation created statutory obligations for some archives, in the majority of cases the process of record-keeping "continued to be a voluntary commitment rather than a duty".

The report noted the extensive portfolio of private archival collections held by "countless individuals, societies and organisations". There had been significant growth too in the archiving of the moving image, sound and photographic materials with some operated as commercial ventures. ${ }^{54}$ The diversity and the priorities of private interests, it said, produced a "complex mixture that will not lend itself to a simple set of actions for greater co-ordination or for sharing". A right of public access could not always be assumed where commercial or self interest was involved, although controlled access, often to "support a range of learning and social outcomes", was prevalent among many private archives.

The report came up with a number of recommendations designed to enhance a sustainable archival heritage. These included:

- establishing an Archives Gateway, i.e., an "all-purpose entry point for people seeking archival material"

- positioning UK archives to be "key contributors to local regional and national social and economic objectives"

- raising standards and "enhancing teaching and learning" by releasing the "potential" of archives

- increasing community participation in UK archive activities especially "hard-to-reach communities"

- integrating business, private and specialist archives as "integrated components of our national heritage"

- encouraging the "creation and sustainability" of moving image, sound, photographic and digital archives through support for relevant strategies 
- modernising service management and workforce development

- establishing a forum within which the four home nations would participate to "coordinate the development of the recommendations in this report". 55

It seems that, from the mid 1990s onwards, during the first decade of public access to the internet, libraries and policy makers were endeavouring to make sense of the digital revolution and contemplate the challenges and opportunities this would bring throughout the libraries and archives sector. But time moves on and the question that now arises in the context of this current discussion is how far this analysis has strengthened archives policy and, in particular, digital preservation - which is at the heart of the challenge already here.

\subsection{Development of a UK digital preservation strategy for archives and records}

\subsubsection{The National Archives}

It is interesting that a country report to an international study ${ }^{56}$ on the impact of copyright law on digital preservation, published in July 2008, opened with the remark: "there is no national strategy as such for digital preservation in the UK" ${ }^{57}$ The country report noted that different sectors were working on relevant aspects of digital preservation and some attempt was being made to coordinate this work. However, it was implicit within the report's findings that a number of problems still needed to be addressed before an effective policy on archiving could be heralded. So, what has been accomplished to date and what further action is needed?

With regard to national archives one of the most important developments has been the launch of TNA's 'Digital Continuity Project' ${ }^{58}$ TNA has recognised that it has to move from an institution "whose main medium of operation is paper-based to one which mainly deals in electronic records". Most government records were now in electronic form and the amendments made by the Freedom of Information Act 2000 (FOIA) meant that the previous practice of not transferring records until they were 30 years old had changed. The old system was based on the regime, established under the Public Records Acts, ${ }^{59}$ whereby records were normally closed and therefore unavailable to the public for this period. Now, to facilitate better access to the archives generally TNA has placed online the National Register of Archives (NRA) which was first established in catalogue form in 1945. The indexes within NRA, which number in excess of 44000 , provide details on the "nature and location of manuscripts and historical records relating to British History". 60

With regard to the records themselves, TNA has now recognised that their digital form creates vulnerability and therefore they need to be secured as soon as possible to avoid corruption or loss. It anticipates a substantial increase in the volume of such records being deposited. In that case, and as time moves forward, storage arrangements must embrace preservation policies to ensure the continuity of the archive. TNA notes that the average lifespan of a typical piece of digital information is 5-7 years. ${ }^{61}$ It reports that "vital government information is now becoming unreadable or even unrecoverable, because the media it's stored on is deteriorating, hardware and software is no longer in use, or successor products can't read old files". ${ }^{62}$ This may mean migrating electronic records to new formats as they become obsolete. ${ }^{63}$ 
Following an independent review ${ }^{64}$ of the ' 30 year rule' initiated by the Government, the review team recommended a transition to a ' 15 year rule' to be implemented incrementally over the same period. This would apply to the transfer of public records to TNA and other places of deposit and include public access. However, the review panel was concerned that this amendment would "prove meaningless" if the official records did not themselves survive:
"In the course of conducting this review, we have discovered that this is a real concern and pressing problem; not only from the deficiencies of current record-keeping practices, but also (and more importantly) from the long-term vulnerability of the digital records now produced by all governments, and by businesses, organisations and institutions around the world, and additionally from the challenging complexity of managing them." 65

The review panel reported that "conventional paper-based procedures of preservation" were "no longer suited or appropriate". The digital record faced both "rapid obsolescence" rather than "slow decay". It was already on the record that important digital records had been lost due to unsupported software, corrupted storage media or lack of preservation systems. In addition, there were other problems related to the "easy come easy go" nature of some digital material such as e-mail, alongside "problems of authentication; the chaotic situation of "data litter" with no common approach to management; the sheer volume of data that is created; and finally its variety, encompassing databases, emails, presentations, websites and video as well as conventional papers". Digital records should be reviewed by departments no later than ten years after they were created and such material should be placed in a "stable storage environment". If not addressed there was a "real danger" that the official record might not survive. It was "difficult to overstate just how disastrous this would be". 66 The net result has been a government decision to reduce the period of closure of the record progressively to 20 years, but with special protection for papers of the Royal Family and the Cabinet.

There is no firm word as yet on what the Government intends to do about the other concerns raised by the review panel. However, there have been a series of 'market soundings' with potential suppliers familiar with delivering technology and technology services to government. Consideration is being given to addressing the risk factors associated with digital continuity via adoption of "information management best practice guidance and standards across government, supported by a framework of assured professional services and technology". The hope is that such an approach will encourage government departments to take "informed, cost-effective and needs-driven decisions to mitigate specific digital continuity risks". From January 2009 the Government says that it will begin to utilise suppliers to validate this approach while undertaking "rigorous assessment" of the technologies and services that might support such proposals. ${ }^{67}$ In the meantime TNA continues to pursue its chosen priorities which are to "lead and transform information management" as well as to "guarantee the survival of today's information for tomorrow". 68

\subsubsection{The British Library}

With regard to BL one of the key objectives continues to be how to redefine its role in the digital age. It notes that the scale and scope of its collection ${ }^{69}$ exacerbates the challenges that BL must overcome particularly in underpinning "the UK's contribution to 
world-class scholarship, creativity and business innovation" ${ }^{70} \mathrm{BL}$ maintains that it is continuing to "develop expertise and technological applications to improve our paper conservation methods" and, with regard to digital material, is working with the "core research base" comprising Joint Information Systems Committee (JISC) TNA and the UK Research Councils to "solve the substantial technical challenges associated with long-term storage of the electronic record". ${ }^{71}$ In a fundamental way, since 2005, it has also begun to take on the challenge of redefining it role and purpose in response to "the information revolution of the 21 st century". 72

Since 2005, with the support of Microsoft and other partners, BL has begun to build a National Digital Library (NDL). ${ }^{73}$ To assist with existing data held in different formats Microsoft installed 'Virtual PC 2007'. This allows users to run multiple operating systems simultaneously on the same computer so as to "unlock 'legacy' Microsoft Office formats dating back 15 years or more". ${ }^{44}$ The intent behind NDL is to "provide sophisticated storage, preservation and access to the nation's digital content" initially ingesting material that is "born digital" such as websites and e-journals collected as part of BL's voluntary deposit programme.

Legal deposit of works in the UK is governed by the Legal Deposit Libraries Act 2003 and Sections 6-8 of the Act make provision for deposit and regulation of non-print publications. In that context BL, in conjunction with the other legal deposit libraries, is continuing to "review its processes for acquiring categories of material not covered by previous legislation including offline (i.e., hand-held items such as CD-ROM) and online electronic publications". 75 An independent Legal Deposit Advisory Panel (LDAP) was established by the Government in September 2005 to advise the Secretary of State on the implementation of the Act. ${ }^{76}$ In March 2007 LDAP re-launched the voluntary scheme for the deposit of offline digital and microform publications first published as a voluntary code in $2000 .^{77}$

Meanwhile, work continues to develop the NDL as a "key part of the UK's research infrastructure". It is focussing initially upon the material submitted since 2000 under the voluntary scheme and e-versions of all its collection items that have already been digitised. Thereafter, NDL is designated to become the "central element of our approach to digital collection management".

Other similar programmes are also ongoing such as bulk digitisation of BL's newspaper collection and continuing work with JISC on searchable online access to BL's 19th century newspaper archive. ${ }^{78}$ Work also continues of BL's 'Smart Crawler' project with the US Library of Congress and others for the automated targeting and capture of eligible websites for archiving.

BL is also lead partner in an Arts and Humanities Research Council (AHRC) funded Digital Lives Research Project ${ }^{79}$ that ran from September 2007 to March 2009 and is a 'pathfinder' study of personal digital collections. Its rationale is based on the fundamental changes taking place in the "creation, transmission and retention of personal and cultural information" whereby information is held by means of "digital media, communal and collective history, family memory and private reminiscence”. BL comments that:

"As the move takes place from a memory based on physical artefacts, to a hybrid digital and physical environment, and then increasingly shifts towards new forms of digital memory, many fundamental new issues arise for research institutions such as British Library that will be the custodians of and provide research access to digital archives and personal collections created by individuals in the 21 st century." 
BL anticipates that the knowledge gained from the project will apply to a "wide range of individuals and research repositories".

To assist in the broader task, in 2006, BL published a strategy for digital preservation which aims, by 2016, to house all of BL's digital collections within a secure digital repository, presumably including NDL. It aims to establish preservation strategies are in place "to ensure continued access to these collections" and a "preservation watch mechanism" is intended to identify and give early warning of the need for preservation action. ${ }^{81}$ The strategy includes development of BL's Digital Object Management (DOM) Programme which aims to "preserve ... digital material in perpetuity" in a form that can be accessed, is easy to find, can be viewed using current technology and where users can, where possible, "experience material with the original look and feel" ${ }^{82}$ The challenge intensifies as the type and character of relevant digital material diversifies and the duration of its existence and therefore its availability for capture ever narrows. ${ }^{83}$

\subsubsection{Other preservation groups, recent initiatives and proposals}

A further participant in preservation management, since 1984, is NPO. This was established by the British Library Board with the objective, at that time, to raise awareness of preservation issues. Since then BL asserts that NPO has become "a major force in supporting the preservation of library and archive material in the UK and Ireland" ${ }^{84}$ It is contributing to the process of understanding the state of preservation of libraries, archives or museum collections through the operation of its Preservation Assessment Survey ${ }^{85}$ It also offers strategy development via management consultancy, such as its participation, for example, in the INFOSAVE project to "establish a facility for mass deacidification" in the UK. ${ }^{86}$

It is important that this expertise cascades to other sectors. In late 2003 the UK Web Archiving Consortium (UKWAC) was established, supported by TNA, BL. JISC, the National Libraries of Wales and Scotland and Wellcome Trust, to approach website owners for permission to "capture" content relevant to consortia member's subject interest or domain. The aim is to "understand UK web space" and seek to build "a selective yet useful national archive".

In a survey, the results of which were reported in 2008, the international trade association for non-profit publishers known as the Association of Learned and Professional Society Publishers (ALPSP) ${ }^{87}$ revealed that more than $90 \%$ of its membership believed long-term preservation to be a 'critical issue'. The principal reason put forward was recognition of the importance of this to members' customers. ${ }^{88}$ There was a strong desire within the organisation for the development of "best practice" and industry standards that could be followed.

In fact, in respect of some aspects of the task, such information and guidance has been available for several years covering a range of archival issues. Since 2003 TNA has developed, in four volumes, generic requirements for sustaining electronic records over time based on BS ISO 15489 information and documentation - records management standard. ${ }^{89}$ In addition, following a consultation exercise with interested parties in 2003-2004, TNA produced an updated 'Standard for Record Repositories'. ${ }^{90}$ This was first launched in 1990 by the Historical Manuscripts Commission which, from 2004, has added guidance on the "preservation of digital and other electronic records in the absence of definitive standards in this developing field". 
For private owners of records, "whether individuals, families, businesses or other institutions", a National Advisory Services department at TNA offers support "on any aspect" of archival care. If the rights holder wishes it can also arrange for materials to be transferred to "a suitably-equipped record repository" which can undertake this work on their behalf. ${ }^{91}$ Advice on licensing or transfer arrangements can also be supported.

In 2006, TNA followed its four volume series, with a set of requirements for electronic records management systems. ${ }^{92}$ It reported that the main issue remained the same viz. how to preserve records "or more precisely copies of records enabling reproduction of the record in an authentic form, through time and across technological changes". This could not be achieved simply by placing digital records in "secure environmentally controlled conditions". Such media would ultimately decay, placing access to it in jeopardy. Migration to current technology needed to be performed by a set of procedures that would ensure the integrity of the record. In addition, the management of metadata must ensure that the context of the creation and use of the records is "kept in close association with the content", ${ }^{93}$ to assist the process of searching the catalogues and lists held within.

Another ongoing problem, which is being tackled, concerns the lack of technical documentation about hardware, software and operating systems "when its subject matter is obsolete (which often means one year old)". ${ }^{94}$ TNA has, in response, established a database called PRONOM - a web-enabled repository of information of the kind just described. Its aim is to serve as a "major tool to support the practicalities of digital preservation". 95

To add to this wealth of data, NPO has produced a 'Preservation in Practice Series' offering basic guidance on digitisation and management of archive collections. ${ }^{96}$ Also, the Digital Preservation Coalition (DPC), established in 2001 and formally launched by the House of Commons in 2002, is working to preserve UK digital resources and with others internationally "to secure our global digital memory and knowledge base". In 2008 it published a report assessing how different sectors were approaching digital preservation in the commercial, public and regulated industries sectors. ${ }^{97}$ It produced a set of recommendations for organisations, government, funding and regulatory bodies which were designed to improve the UK's digital preservation capability.

There have been further policy clarifications since 2008 that have taken matters forward. One was an overarching re-affirmation of government determination to manage information better. No doubt the sub-text for this report ${ }^{98}$ was concern about the catalogue of failures across government in maintaining the security and integrity of PSI. ${ }^{99}$ It recognised the "unprecedented change in the way information is created, stored, disseminated and used" and recognised that information management needed to be partnered with good knowledge management to "maximise the value of information" and ensure that it leads to "more informed decision making". This required "clear standards for the keeping and capture of records" and with this in mind a Knowledge Council would be established to "lead government" in this process. ${ }^{100}$ It was stated that the latter together with the Chief Technology Officer's Council (CTO) - the cross-government body established to deliver the 'Transformational Government' Implementation Plan, ${ }^{101}$ - would work with TNA to establish a "common approach to government information capture systems". ${ }^{102}$ 
The second initiative, announced in May 2009, is a consultation on future policy for archival services, ${ }^{103}$ which builds on progress since the last policy statement back in 1999. ${ }^{104}$ The main proposals, for which views are sought, are ideas for integration and collaboration of services; strengthened leadership within the sector leading to a more responsive, skilled workforce; more coordination in the management of digital information, to render it "accessible now" and "discoverable" in the future; better access for citizens, via catalogues and digitised archive content, to relevant resources at a time and place that suits the individual; and encouragement to participate in "cultural and learning partnerships" promoting a "sense of identity and place within the community".

There appears to be an appreciation here in this consultation that, while archives are of obvious importance to future generations, they also have great significance to individuals and communities today. As information technology continues to quicken its pace of development and change, it is vital for those alive today, for governments and policy makers, for businesses and organisations, to develop publicly funded archives that can deliver well on content, accessibility and relevance.

The latest report, of some relevance, is the Final Report on the Government's "strategic vision for ensuring that the UK is at the leading edge of the global digital economy". ${ }^{105}$ The Final Report is described as one of the central policy commitments in the Government's 'Building Britain's Future' plan and draft legislative programme. ${ }^{106}$ Other than orphan works there is not a great deal in the report of application to archive policy, but the Government does confirm that it continues to "consider the scope to amend the copyright exceptions regime" and intends a further consultation on the issue later in 2009.

With regard to orphan works, i.e., works that remain in copyright but the author cannot be found, even after "diligent search", the Government announced in the report its intention to introduce legislation "to enable commercial schemes for dealing with orphan works to be set up on a regular basis". ${ }^{107}$ It notes the work done by the European Commission on proposals for "voluntary" schemes, based on licence grants by collecting societies for commercial and non-commercial use, but notes that the operators of such schemes cannot avoid potential criminal liability or be absolved from it without a change to UK law. Under this proposal, rights could be granted without consent of the rights holder, subject to minimum requirements and safeguards. The Government recognises, however, that more work is needed to prepare this initiative as draft legislation.

Such plans are bound to be welcomed by the archive community. The report notes, for example, that up to $40 \%$ of the archive of BL can be categorised as orphan works. This represents "an enormous cultural heritage to which the public cannot get access". By changing the law "mass digitisation projects" could put forgotten works "back digitally on to the cultural map". ${ }^{108}$ A change in the law would also clarify the BBC's position, since it estimates that "around 1 million hours of programmes sits in its archives, where the complexity associated with identifying, checking and clearing rights will require imaginative new solutions in order to be addressed".

Not all these issues will be resolved by tackling orphan works, although the BBC notes that such works are being created in growing numbers. Other concerns come from the authors themselves who fear that evidence of ownership, and therefore potential royalty income, can be lost when a work, such as a photograph, is routed to publication on a website. The result is that cultural assets remain suppressed "because of the legal difficulties associated with using these works". The questions raised here and the 
implications for archives are likely to continue to be debated as they represent some of the most intractable problems that need to be addressed if the copyright and licensing environment for archivists, users and right holders is to work satisfactorily for all concerned.

\section{Conclusion}

It is likely that many people, when asked about the purpose of archives, will talk in terms of the value of recording today's information for future generations. That, indeed, is a crucial function and responsibility both of government and the myriad of organisations and individuals who hold records of value of this kind. But the position is more complicated than that. Archive policy is not and should not be simply about locking away information safe from destruction, preserved in tact for the future. Archives are also within and about the here and now and much more widespread, as is evident from a comment in the Final Report on Digital Britain that public service content is now being delivered "from a much wider range of sources than in the analogue age". ${ }^{109}$ It also draws the link between information and a vibrant economy. The former feeds the latter but, when the economy suffers and institutions fail, its "memories, archives, values and community relationships" can be lost, destroying what in some cases have been built up steadily through many generations. ${ }^{110}$

In the days of the offline world of printed material, the channels through which information was created, stored and published were clear and understood. Book publishers and newspaper operators inhabited the private sector and public sector material was managed on behalf of government and Parliament by Her Majesty's Stationery Office. Legislation to secure the public record of such works was established and public access given via the deposit libraries. Digitisation has rendered that simple model redundant and blurred the distinctions between publisher, broadcaster and archivist. Digital technology has created an information and communications resource that is, in some respects, democratically open to everyone to participate. No matter who we are we can now create and publish material, whether text, film or imagery to as wide a circle of people as we choose. The benefit of mass distribution and availability is clear. But, in so doing, the physical copy of the record is reduced to a digital form that is hugely more vulnerable to loss or destruction than the former.

This poses enormous challenges for our national archives. The upheaval of photographic methods that has just finally abandoned film manufacture in favour of the digital camera, means that paper based photo 'albums' will disappear in favour of digital files. This illustrates the dilemma facing archivists in the era when most information is likely to be 'born digital' and reside in any storage device. The same will apply to correspondence where letter writing has given way to e-mail, text and twitter. In the broadest sense, therefore, everyone today has the capacity to become an archivist. It is no longer an activity that only the public institutions participate. That is why it is important that information and guidance on how to create and sustain archives is available widely for all to use. It is also interesting to observe how libraries and broadcasters, such as the $\mathrm{BBC}$, are developing repositories of cultural and historical information to which everyone can contribute. ${ }^{111}$ These facilitated resources need to be protected. 
In general terms storage costs have been underestimated. With the current economic crisis upon us there is a danger that good work may be lost or diluted while a sustainable solution is sought.

For bodies like TNA and BL there are many challenges to be faced. The emphasis today is about delivering archive 'services' rather than simply creating a repository. In the digital age a by-product of exposure to digitisation is the demand for instant access. The expectation becomes habitual. Yet, for those libraries engaged in archival work, they can readily run into trouble when pressure is exerted to place archived material online. In some instances instant access may equal invasion of privacy, possibly leading to costly and irritating redaction of documents which name individuals. Yet it does seem counter intuitive for serious researchers to have to travel to view an online resource, for example BL's restricted access online materials.

At present the legal framework leaves libraries vulnerable to risk if right holders have not consented to publication. Indeed, decisions not to archive some material at all are being taken for the similar reasons. It is welcome that the UK Government and the EU are looking at the copyright exceptions applicable to this activity, but the necessary changes in the law need to be made soon. Respecting the interests of right holders, particularly in relation to decisions taken by libraries as to public access to their archived material is not an easy question to resolve. The rights themselves may continue to be held by the authors or by third parties and, in many instances, material that may be presented for archiving will involve multiple works, sometimes running into the thousands. Tracking these, particularly if they are 'orphan works', may very well defeat the most determined archivist, not only on grounds of effort, but the accumulated risk involved in potentially infringing existing rights.

A further problem that is clearly evident relates to the supremacy of contract over copyright in which those rights may be adapted by licence terms for the duration they are held. This raises significant issues for archivists, particularly when engaging in projects that involve the private sector. ${ }^{112}$ If the latter holds the rights to the original works, the archiving library may find that the terms forbid retention of the material once the licence concludes. Alternatively, where the private sector becomes a participant in the archiving process, for example in the archiving of PSI or of specific library collections, the contract terms that regulate their commercial involvement may not necessarily ensure public access on terms acceptable to all parties. This is indeed the reason why the 'free our data' campaign, ${ }^{113}$ exists where its proponents argue that free public access to PSI is a right that should not be compromised by private sector participants seeking a return on their investment. From the private sector's position, however, they argue that others are free to develop similar collections. What they seek is a return on access to the version they have produced, which benefits from the skill, labour and proprietary tools they have used to create an accessible resource.

The reality is that governments are not minded to take on the full expense themselves of managing the archiving of public sector information, particularly when the cost involved is in the digitisation and restoration of historical records. Not everyone can secure what they want here in terms of archiving the public record. Private sector participants are bound to be part of the equation, since government is never going to resource the process fully and may, in any case, lack the expertise to undertake the work. That will inevitably mean that access to such archived material will be contractually regulated to ensure a return on the investment. 
Archiving policy today, therefore, cannot be an exact science. Digitisation has let information out of the bag. Everyone can both create it and access it subject to right holder restrictions.

This is of course potentially a very good development and yet we are at the very beginning of the digital era. For libraries and archivists, responding to this is an immense challenge. Archivists continue to express surprise at the historic areas people choose to investigate. This makes the choices as to what 'born digital' material to select and keep doubly difficult to determine. What is needed is an authoritative, reliable, permanent, official, non-corruptible online resource. A process has to be created to 'capture' digital content before it evaporates and legal regulation needs to be adjusted to enable TNA, BL and others to select, preserve and present digital archive material in an accessible and secure manner. It is fair to say that the libraries themselves have a reasonable idea now of what needs to be done and where the gaps lie in regulatory arrangements. They understand too that a pragmatic response is required in their dealings with the private sector. The real question now is whether the regulators themselves can reach a consensus that goes far enough to meet the necessary concerns. There are steps that can be taken and these have been identified. The issues do not just concern the UK alone but the international community as a whole. We wait with interest to see what the future holds.

\section{Acknowledgements}

My thanks to Joy Caisley, Julian Ball, Chris Fowler and Jayne Tweedle of the University Library at Southampton for their advice and support in the researching and writing of this paper.

\section{Notes}

1 Strategic Plan 2008-2009 The National Archives.

2 Annual Report and Resource Accounts 2006-2007, HC 874 (The National Archive, TSO 24 July 2007).

3 Op. cit., note 1, ante. TNA also comprises the Public Record Office (PRO) established in 1838 to reform the holding of government and court records and the Historical Manuscripts Commission (HMC) which merged with PRO in April 2003 so as to minimise overlap between inspection and advisory services operated by the predecessor organisations. See: Standard for Record Repositories, 1st Edition, The National Archive, 2004). It also includes Her Majesty's Stationery Office (HMSO) which had previously been the focal point for the management of Crown copyright and database rights, publication of legislation and of official publishing guidance.

4 Redefining The Library - The British Library's strategy 2005-2008. BL also has a 42 acre site in Boston Spa in Yorkshire for storage and dispatch of material and other facilities in London.

5 The British Library - Providing services beyond the Reading Rooms, Report by Comptroller and Auditor General, HC 879, Session 2003-2004:28 July 2004.

6 Copyright Act 1911 as amended by Legal Deposit Libraries Act 2003. The other legal deposit libraries in the UK are the National Library of Scotland; the National Library of Wales; The Bodleian Library, Oxford; The University Library, Cambridge; and Trinity College, Dublin.

7 Taking forward the Gowers Review of Intellectual Property - Proposed changes to copyright exceptions, UK Intellectual Property Office 2008 para 8.

8 The Gowers Review of Intellectual Property 2005-06. 
9 Ibid., Recommendation 10A. Librarians and digitisation specialists report that 'format shift' is a huge problem in other ways. For example, if a theses owner has given permission for their thesis to be microfilmed, this does not mean that libraries have permission to digitise it. This can cause problems when libraries wish to digitise their thesis collections to put into their institutional repositories, as they have to go back to the rights owners and after a few years this task is fairly difficult, especially if the author is female and has changed surname.

10 Ibid., Recommendation 10B.

11 Op. cit., note 7 ante, paras 170-187.

12 Copyright Act 1961 ss. 16, 53a-b (as amended). Act No. 2 of 12 May 1961 relating to Copyright in Literary, Scientific and Artistic Works, etc. (as amended 17 June 2005).

13 The Gowers Review of Intellectual Property Extending the UK's copyright exceptions, Barbara Stratton, Senior Policy Adviser CILIP, 15 September 2008.

14 British Library submission to the UK-IPO on 'Taking forward the Gowers Review of intellectual property: proposed changes to copyright exceptions' 2008.

15 Ibid., p.31.

16 Ibid., p.7.

17 Ibid., BL also drew attention to a number of licenses that referred to 'internal business use' - a term not appropriate to the context of libraries and the access they provide to the public.

18 Ibid., BL in its Recommendation also suggested draft text for revised legislation based on wording from the Irish Copyright Act - Copyright and Related Rights Act, Number 28 of 2000 .

19 (C) the future - Developing a Copyright Agenda for the 21st Century, (Intellectual Property Office, Department of Innovation, Universities and Skills, December 2008).

20 Op. cit., note 14 ante.

21 See further: http://ec.europa.eu/information_society/eeurope/i2010/strategy/index_en.htm. See also Strategy for an innovative and inclusive European Information Society, (European Commission, Information Society and Media, April 2008).

22 Ibid.

23 Commission Staff Working Document accompanying the Communication ....on Creative Content Online in the Single Market (COM(2007) 836 final, Brussels 3 January 2008).

24 Final Report on the Content Online Platform (May 2009). This report is based on discussions which took place in the framework of the 'Content Online Platform', as perceived by the services of the Information Society and Media Directorate-General of the European Commission.

25 Ibid., p.4. See further: Council conclusions of 20 November 2008 on the development of legal offers of online cultural and creative content and the prevention and combating of piracy in the digital environment (Official Journal C 319, 13.12.08 P. 0015-0017).

26 See Section 3.1 ante.

27 Green Paper, 'Copyright in the Knowledge Economy' (COM(2008) 466/3, 16 July 2008).

28 The Green Paper defines the term as "commonly used to describe economic activity that relies not on 'natural' resources (like land or minerals) but on intellectual resources such as know-how and expertise. A key concept of the knowledge economy is that knowledge and education (also referred to as 'human capital') can be treated as a commercial asset or as educational and intellectual products and services that can be exported for a high value return. It is obvious that the knowledge economy is rather more important for those regions whose natural resources are scarce."

29 Op. cit., note 27 ante, p.3.

30 Directive 2001/29/EC on the harmonisation of certain aspects of copyright and related rights in the information society Off Journal L167/10-19, 22 June 2001). 
31 Commission Recommendation of 24 August 2006 on the digitisation and online accessibility of cultural content and digital preservation (2006/585/EC, Off Journal L 236/28).

32 Final Report on Digital Preservation, Orphan Works and Out-of-Print Works (i2010: Digital Libraries High Level Expert Group - Copyright Subgroup 4 June 2008).

33 Response from the British Library to the Green Paper on Copyright in the Knowledge Economy.

34 See: Council conclusions of 20 November 2008 on the European digital library EUROPEANA (Off Jnl C319/18 13 December 2008).

35 See: http://www.europeanvoice.com/Article/63159.aspx.

36 Ibid.. Digital preservation "refers broadly to the series of managed activities necessary to ensure continued access to digital materials for as long as necessary, such as collection, description, migration and redundant storage". Source: Besek et al. International Study on Copyright and Digital Preservation' p.140 (2008).

37 Convened by the Chartered Institute of Library and Information Professionals.

38 European Commission Green Paper on 'Copyright in the Knowledge Economy' COM(2008) 466/3 - Response by LACA: the Libraries and Archives Copyright Alliance.

39 UK Government response to European Commission's Green Paper - 'Copyright in the Knowledge Economy'.

40 Op. cit., note 38 ante.

41 Explained in: Study on Copyright Limitations and Exceptions for Libraries and Archives, World Intellectual Property Organisation, Standing Committee on Copyright and Related Rights, 17th Session Geneva, 3-7 November 2008, pp.19-20.

42 Art 9 TRIPS requires the European Community to comply with the Berne Convention. Art 9(2) Berne reads: "It shall be a matter for legislation in the countries of the Union to permit the reproduction of such works in certain special cases, provided that such reproduction does not conflict with a normal exploitation of the work and does not unreasonably prejudice the legitimate interests of the author."

43 This is the general exception clause to exclusive rights of the holders of copyright.

44 Op. cit., note 30 , ante

45 Op. cit., note 39 ante.

46 Listening to the Past, Speaking to the Future - Report of the Archives Task Force of the Museums, Libraries and Archives Council, 2004.

47 BBC News reported at the time that "this was not because the data had deteriorated, but the format chosen to record it had long been abandoned and so consequently devices to read it had disappeared as well". The book had been stored on 12 inch videodisks read by a laser disk player that became obsolete and a working model of the equipment was becoming very rare. The digital record was finally recovered in 2002. See further: http://news.bbc.co.uk/1/hi/ technology/2570731.stm.

48 Government Policy on Archives Cm 4516, Lord Chancellor's Department, December 1999. In 2001 an 'e-Government Policy Framework for Electronic Records Management' was also published by the PRO along with 'Sustainable electronic records - Strategies for the maintenance and preservation of electronic records and documents in the transition to 2004'. 2004 was the deadline fixed for all newly created public records to be electronically stored and retrieved.

49 One such initiative is 'The Web Continuity project', launched in 2003 and led by TNA which aims to "develop a comprehensive programme of website archiving and web link management to ensure continued access to government information".

50 A national preservation strategy for library and archive collections in the UK and Ireland, principles and prospects, National Preservation Office, The British Library, January 2001.

51 Archives in the Digital Age - A Study for Resource, Missenden Consulting LLP, December 2002. 
52 Framework for the Future - Libraries, Learning and Information in the Next Decade, Department for Culture, Media and Sport, February 2003.

53 Ibid., p.18.

54 An illustration of this is the BBC's 'WW2 People's War' archive in which the public were invited, between June 2003 and January 2006, to contribute their memories of World War II to a website now available at www.bbc.co.uk/ww2peopleswar/. An archive of 47000 stories and 15000 images is the result. A current project is 'Memoryshare - the days of our lives' which is collecting a wide range of peoples' memories on many topics. See further: www.bbc.co.uk/ memoryshare.

55 Ibid., pp.7-9.

56 International Study on the Impact of Copyright Law on Digital Preservation - A joint report of The Library of Congress National Digital Information Infrastructure and Preservation Program; The Joint Information Systems Committee; The Open Access to Knowledge (OAK) Law Project and the SURFfoundation, July 2008.

57 Ibid., Report by Adrienne Muir, Department of Information Science, Loughborough University, UK.

58 See further: www.nationalarchives.gov.uk/digital continuity: "The need for a governmentwide shared service that addresses digital continuity issues was recognized in 2007 and the requirement to take action is referenced in the $2008 \mathrm{HM}$ Government guide, 'Managing information risk' aimed at Accounting Officer, Board members and Senior Information Risk Owners."

59 Public Records Act 1958 (c. 51) as amended by Public Records Act 1967 (c. 44) which reduced the period of records lock-down from 50 years to 30 years. Recommendations.

60 TNA reports that the records themselves have been created by 46000 individuals, 9000 families, 29000 businesses and 75000 organisations.

61 TNA reports for example that $51 / 4$ inch disks, "though commonplace 20 years ago" are now obsolete; CDs and DVDs have "finite lifespan"; software such as WordStar, used to view documents, "cannot easily be run modern machines".

62 If you do not protect your digital assets, they cannot protect you - digital information matters, The National Archives, October 2007.

63 See further: www.nationalarchives.gov.uk/electronicrecords/seamless_flow/default.htm.

64 Review of the 30 Year Rule, 29 January 2009. This was an independent review Chaired by Paul Dacre working with Professor David Carradine and Sir Joseph Pilling.

65 Ibid., p.37.

66 Ibid.. It is reported in 'digital information matters', op. cit., note 54 ante, that "an estimated $10 \%$ of the Canadian Government's electronic records are already no longer readable".

67 See further: www.nationalarchives.gov.uk/electronicrecords/digitalcontinuity/suppliers.htm.

68 Living information - The Vision of The National Archives (TNA, July 2007). This is further discussed in its Strategic Plan 2008-09.

69 See notes 4-6 ante. Three million new items are added annually adding to the $625 \mathrm{~km}$ of shelves at the rate of $12 \mathrm{~km}$ per annum. There is on-site space for more than 1200 readers and 16000 people use the collections daily.

70 See further: www.bl.uk/aboutus/stratpolprog/redeflib/role/index.html.

71 Ibid., JISC is part of the Higher Education Funding Council.

72 Redefining the Library - The British Library's strategy 2005-2008, British Library, 2004.

73 NDL's storage facility is intended to have "strict quality and security controls". Items entered into the system will be digitally 'signed' and 'catalogued' using metadata which enable library staff to ensure the digital item has not be interfered with. Three copies of all material will be kept as backup.

74 David Smith (technology correspondent) The Observer, 25 January 2009. 
75 See further: www.bl.uk/aboutus/stratpolprog/legaldep/.

76 Working alongside LDAP is a Joint Committee on Legal Deposit (JCLD) which acts as a forum for publishers and the legal deposit libraries to discuss "the practical implications of the Act and its implementation" LDAP publishes an Annual Report on its work.

77 Code of Practice for the voluntary deposit of non-print publications 2000 was for the deposit of offline or hand-held electronic publications.

78 "Significant sections" of the Sound Archive will also be digitised following on from 4000 hours of sound "which is part of the JISC supported programme to improve access to sound for researchers". Work will also progress with Schools to provide access to "interpreted online resources". See further: www.bl.uk/npo/about.html.

79 See further: www.bl.uk/digital-lives/about.html. Other participants include University College London and University of Bristol.

80 Ibid., One BL spokesperson commented: "Part of our collection of so-called ephemera includes labels from food tins and old theatre tickets. This provides valuable social information and it may be that blogs play that sort of role in the future."

81 British Library Digital Preservation Strategy 2006. In 2006 BL spent $£ 2 \mathrm{~m}$ of its $£ 16 \mathrm{~m}$ annual acquisitions budget on digital material, mainly reference books and journals. By 2020 it predicts that $90 \%$ of all newly published work will be available digitally.

82 Ibid., See further: www.bl.uk/aboutus/stratpolprog/digi/dom/mission/index.html. The general approach was validated by an external review in March 2004 and since then as part of external reviews of BL's IT practices.

83 Paul Cunnea comments in his paper: Selective web archiving in the UK: a perspective of The National Library of Scotland within UK Web Archiving Consortium (UKWAC) that "it has been claimed that the average lifespan of a website is 44 days".

84 See further: www.bl.uk/npo/about.html. An independent Preservation Advisory Panel meets every six months to offer guidance on preservation policy, national programmes and the sharing of preservation know-how. It also acts as a test-bed for strategies that may assist development of tools for collection care.

85 Knowing the need and meeting the need - The state of preservation of the UK's library and archives collections, National Preservation Office, February 2006. The five year project examined " 28 million items - books, documents, photographs and other paper based material - from 79 organisations".

86 See further: www.bl.uk/npo/infosave.html.

87 See: http://www.nationalarchives.gov.uk/PRONOM/Default.aspx.

88 ALPSP is the largest trade association for scholarly and professional publishers. It has more than 360 members in 36 countries "publishing scholarly content in many different ways". Over 10000 journals are published by ALPSP members "as well as numerous books, reports, databases and other products and services".

89 Generic requirements for sustaining electronic information over time: (1) Defining the characteristics for authentic records; (2) Sustaining authentic and reliable records: management requirements; (3) Sustaining authentic and reliable records: technical requirements; and (4) Guidance for categorising records to identify sustainable requirements, (The National Archives, 2003).

90 Standard for Record Repositories, The National Archives. In respect of storage accommodation this is based on British Standard 5454 'Recommendations for the storage and exhibition of archival documents'.

91 See further: www.nationalarchives.gov.uk/archives/Looking_after_records.htm.

92 Requirements for Electronic Records Management Systems - Functional Requirements for the Sustainability of Electronic Records, Version 1, The National Archives, March 2006.

93 Ibid., p.6. 
94 Adrian Brown, 'Preserving the digital heritage: building a digital archive for UK Government records', In: Online Information 2003 Proceedings.

95 It is expected that PRONOM will be expanded into the PLANETS (Preservation and Long-term Access through Networked Services) project - on of several European initiatives on digital preservation. Source: Barbara Sierman, The Jigsaw Puzzle of Digital Preservation - An Overview, LIBER Quarterly, 2009-1.

96 See, e.g., Basic Preservation Guidelines for Library and Archive Collections, National Preservation Office, February 2008. Others in the series deal with managing the archive environment and digitisation projects.

97 Mind the Gap: Assessing Digital Preservation Needs in the UK, Digital Preservation Coalition, 15 February 2006. It was based on a needs assessment survey which revealed that "the level of implementation of digital preservation solutions" was "significantly lower than would be expected given the awareness and commitment that were measured". See p.27. See further: www.dpconline.org/.

98 Information matters: building government's capability in managing knowledge and information, HM Government, November 2008.

99 This refers to a wide range of losses of data within the Ministry of Defence, HM Revenue and Customs and other departments. This data was either sensitive on grounds of national security or because it contained millions of items of personal data about members of the public such as benefit claimants.

100 Council members comprise those with relevant responsibilities within government departments and representatives from the Chief Information Officers and Technology Officers Councils.

101 Transformational Government - Enabled by Technology Cm 6683, Cabinet Office, November 2005.

102 Op. cit., note 98 ante, para. 65.

103 Archives for the 21st century - Consultation draft, HM Government, May 2009.

104 Op. cit., note 48 ante.

105 Digital Britain: The Final Report, Department for Business Innovation \& Skills and department for culture, media and sport, 16 June 2009.

106 Ibid., Building Britain's Future sets out the practical action the Government will take "to build a stronger, fairer and more prosperous country" focusing on "cleaning up politics and reforming our democracy; moving from recession to recovery and planning for a strong economy in the future; and reforming Britain's public services".

107 Op. cit., note 105 ante, p.116.

108 Ibid., p.115.

109 Ibid., p.135. It mentions, for example, public cultural institutions like Tate, the Royal Opera House, the Royal Shakespeare Company, the Film Council as well as museums, libraries, archives and galleries throughout the country.

110 Ibid., p.149.

111 Op. cit., note 54, ante.

112 See, e.g., JISC's partnership with private sector operator ProQuest to capture House of Commons Parliamentary Papers from the 18th - 20th Centuries. See further: www.jisc-collections.ac.uk/.

113 The campaign arises from an article in The Guardian Newspaper's Technology Supplement of 9 March 2006 called 'Give us back our crown jewels', that called upon the UK Government to relax Crown Copyright restrictions on data from agencies such as Ordnance Survey, UK Hydrographic Office and Highways Agency and make this data available free. It saw it as the Government charging for data already collected with taxpayers' money. See further: www.freeourdata.org.uk/. 